\title{
JUVENILE WOOD VOLUME AND ITS PROPORTION TO STEM VOLUME VS. SELECTED BIOMETRIC FEATURES OF SCOTS PINE (PINUS SYLVESTRIS L.) TREES
}

\author{
WITOLD PAZDROWSKI, ARKADIUSZ TOMCZAK, \\ GRZEGORZ KUPCZYK, TOMASZ JELONEK \\ August Cieszkowski Agricultural University in Poznań \\ Department of Forest Utilisation \\ Wojska Polskiego 71A, 60-625 Poznań, Poland \\ e-mail: atomczak@au.poznan.pl
}

(Received: April 28, 2005. Accepted: August 3, 2005)

\begin{abstract}
The aim of the study was to determine whether there is a correlation between breast height diameter, tree height and stem total volume of Scots pines, on the one hand, and volume and proportion of juvenile wood, on the other. The investigations comprised pure pine stands of the IInd, IIIrd, IVth and Vth age classes developed in conditions of fresh mixed coniferous forest.

A distinct curvilinear correlation was found between volume and proportion of juvenile wood in tree stems and breast height diameter, height and stem total volume.

Because of high values of determination coefficients $\left(\mathrm{R}^{2}\right)$, which characterised the above-mentioned correlations, it seems appropriate to use these regularities to assess the quality of the timber raw material regarding the proportions of its volume and juvenile wood in stems of Scots pine trees.
\end{abstract}

KEY WORDS: Scots pine, juvenile wood, breast height diameter, tree height, total stem volume, forest site type, determination coefficient.

\section{INTRODUCTION}

The breast height diameter, in other words, the diameter of the standing tree measured at the height of the breast, i.e. $1.30 \mathrm{~m}$ above ground, is its easiest measurable biometric feature. Together with tree age and height, it is one of the most characteristic features which allow determining numerous elements important for both forest-timber science and practice describing trees and tree stands. Volume tables of standing trees give volumes of individual forestforming tree species on the basis of breast height diameters and tree heights (Grochowski 1973; Czuraj 1991).

The evaluation of true timber properties on the basis of different relationships, which are simple and easy to determine, can contribute to a more rational utilisation of timber raw material.

It is evident from experiments conducted by Pazdrowski (1992) that there is a clear linear correlation in pine trees derived from fresh coniferous forest, fresh mixed coniferous forest and mixed broad leaved forest sites between the proportion of sapwood and heartwood in the volume of the butt log and the share of the two kinds of wood in the cross section of the trunk at the plane of cutting and the breast height diameter of trees. These correlations are directly proportional in each case and can be expressed using the following equation: $y=a+b x$.

The heterogeneity of the structure of wood tissue together with natural defects of the stem effects is the quality and value of timber raw material (Wilhelmsson et al. 2002). From the point of view of raw material quality, juvenile wood constitutes an undesirable component of the stem structure (Pazdrowski, Spława-Neyman, Wojcieszyn 1995; Kretschmann 1998; Bao et al. 2002).

Growth is associated with changes in the organism, which find their expression primarily in the increase of its parts measured in units of length, weight and volume $(\mathrm{Pu}-$ chalski 1969).

The proportion of juvenile wood in the stem changes with age (Larson, Kretschmann, Clark III, Isebrands 2001; Jakubowski 2004). The value of the thickness increment is closely correlated with the size of the tree crown (Assmann 1961; Lemke 1966). A similar regularity can be found with regard to juvenile wood (Pazdrowski, Jakubowski 2000; Jakubowski, Pazdrowski 2003). The formation of juvenile 
wood depends on the concentration of auxins which are created in leaves (needles) during the annual development (Zimmerman, Brown 1971). The part of the bole or trunk situated in the region of the crown is made up mainly of juvenile wood tissue (Hejnowicz 1973; Panshin, de Zeeuw 1980; Hejnowicz 2002).

The aim of this study was to try and establish whether there was a correlation between the diameter of the tree at the height of $1.3 \mathrm{~m}$ over the ground level (i.e. breast height diameter), height, total stem volume, and the volume and volume proportion of juvenile wood in the stems of Scots pine (Pinus sylvestris L.) growing in conditions of fresh mixed coniferous forest site type.

\section{MATERIALS AND METHODS}

The investigations were carried out in the Brynek, Choszczno and Miastko Forest Divisions in pure pine stands of the IInd, IIIrd, IVth and Vth age classes growing in conditions of the mixed coniferous forest site types (Fig. 1).

Breast height diameters of all trees, as well as heights proportionally to the size in the adapted $(2 \mathrm{~cm})$ diameter sub-classes, were determined on the established 0.5 ha experimental plots. After obtaining thickness-height characteristics of the trees, dimensions of three sample trees representing the main stand, i.e. the first three Kraft classes, were determined by means of the Urich II method (Grochowski 1973). The total of 48 trees were selected, next the selected trees were cut and the experimental material in the form of discs cut whiteout bark out from the centre of $2 \mathrm{~m}$ long sections were colleted.

In the course of laboratory investigations, disc samples were used to measure the width of the early and late wood in the consecutive annual rings in four geographical world directions: north, south, east and west. In the case of the discs collected from the plane of cutting of sample trees, me-

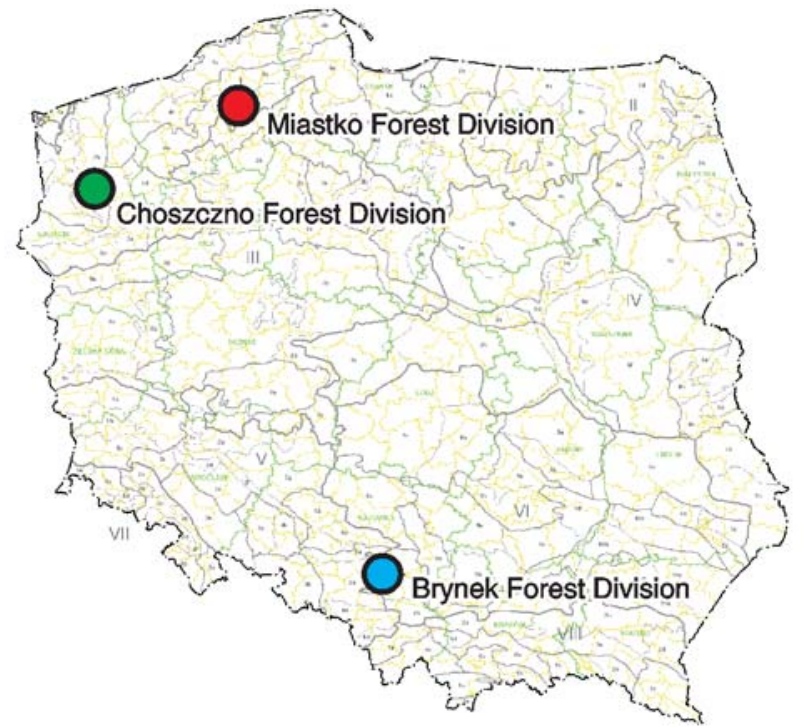

Fig. 1. Distribution of the experimental objects. Map. Source: Principles of Silviculture (2003).

asurements were initiated from the pith moving towards the circumference, whereas in the case of those cut out from the centre of the $2 \mathrm{~m}$ long sections, the measurements were made moving from the circumference towards the pith. The adapted procedure allowed, later on during the laboratory work, to determine the true proportion of juvenile wood in model tree stems. The performed measurements were carried out using an electronic increment meter coupled with a computer equipped with the Codim Increment Meter program.

Next the ratio of width of the late wood zone to the early wood zone was calculated in individual annual rings in the sampled discs from sample trees. Values calculated in this way constituted the basis which allowed distinguishing ju-

TABLE 1. Statistical characteristics of selected biometric traits of Scots pines (Pinus sylvestris L.) growing in conditions of fresh mixed coniferous forest.

\begin{tabular}{|c|c|c|c|c|c|c|}
\hline Age class & $\begin{array}{l}\text { Measures } \\
\text { of position and scatter }\end{array}$ & $\begin{array}{l}\text { Breast height } \\
\text { diameter }[\mathrm{cm}]\end{array}$ & $\begin{array}{l}\text { Height } \\
{[\mathrm{m}]}\end{array}$ & $\begin{array}{c}\text { Stem volume } \\
{\left[\mathrm{m}^{3}\right]}\end{array}$ & $\begin{array}{l}\text { Juvenile wood } \\
\text { volume }\left[\mathrm{m}^{3}\right]\end{array}$ & $\begin{array}{l}\text { Ratio of juvenile wood volume } \\
\text { to stem volume }\end{array}$ \\
\hline \multirow[t]{5}{*}{ II } & Mean & 15.88 & 16.73 & 0.141 & 0.054 & 0.3817 \\
\hline & Standard deviation & 4.12 & 2.30 & 0.082 & 0.045 & 0.1498 \\
\hline & Variability coefficient [\%] & 25.96 & 13.77 & 58.05 & 84.68 & 39.25 \\
\hline & Minimum & 8.50 & 11.80 & 0.050 & 0.010 & 0.1154 \\
\hline & Maximum & 22.00 & 20.40 & 0.290 & 0.203 & 0.7171 \\
\hline \multirow[t]{5}{*}{ III } & Mean & 23.42 & 22.45 & 0.421 & 0.058 & 0.1386 \\
\hline & Standard deviation & 4.87 & 1.86 & 0.225 & 0.022 & 0.0750 \\
\hline & Variability coefficient [\%] & 20.80 & 8.26 & 53.39 & 38.56 & 54.10 \\
\hline & Minimum & 17.00 & 20.30 & 0.160 & 0.030 & 0.0698 \\
\hline & Maximum & 32.00 & 26.70 & 0.860 & 0.110 & 0.3125 \\
\hline \multirow[t]{5}{*}{ IV } & Mean & 25.46 & 22.61 & 0.493 & 0.111 & 0.2257 \\
\hline & Standard deviation & 4.93 & 1.86 & 0.217 & 0.049 & 0.0548 \\
\hline & Variability coefficient [\%] & 19.38 & 8.21 & 43.99 & 44.24 & 24.27 \\
\hline & Minimum & 18.10 & 19.40 & 0.172 & 0.041 & 0.0874 \\
\hline & Maximum & 32.25 & 25.80 & 0.824 & 0.209 & 0.2997 \\
\hline \multirow[t]{5}{*}{ V } & Mean & 33.27 & 26.40 & 1.108 & 0.177 & 0.1594 \\
\hline & Standard deviation & 3.73 & 1.75 & 0.307 & 0.071 & 0.0365 \\
\hline & Variability coefficient [\%] & 11.21 & 6.61 & 27.68 & 39.94 & 22.89 \\
\hline & Minimum & 27.40 & 23.80 & 0.705 & 0.108 & 0.0989 \\
\hline & Maximum & 37.20 & 28.30 & 1.488 & 0.294 & 0.1979 \\
\hline
\end{tabular}


venile and mature wood on the diameter of successive discs feature. The proportion of the late wood in consecutive annual rings of the stem increased with the distance from the pith, but the observed change was more distinct in discs which derived from sections further away from the live crown (Hejnowicz 2002). A similar correlation was found in each forest division and each age class (Hejnowicz 2002).

The obtained results were analysed with the use of statistical methods. Basic statistical characteristics regression of dependent and independent variables in curvilinear correlations were determined.

\section{RESULTS}

The research results are presented in Table 1 and Figures 2 to 8 . The obtained statistical characteristics of the selected biometric traits of Scots pine stems as well as the volume and proportion of juvenile wood indicate a certain diversification within the analysed population of trees. A relatively high variability (the value of the variability coefficient ranged from 38.6 to $84.7 \%$ ) was found with regard to the volume of juvenile wood, slightly lower - from 27.7 to $58.5 \%$ - when analysing the stem total volume. The variability in the proportion of juvenile wood expressed by the ratio of this wood to the stem volume ranged from 22.9 to $54.1 \%$, and the breast height diameter of trees to their hei-

a

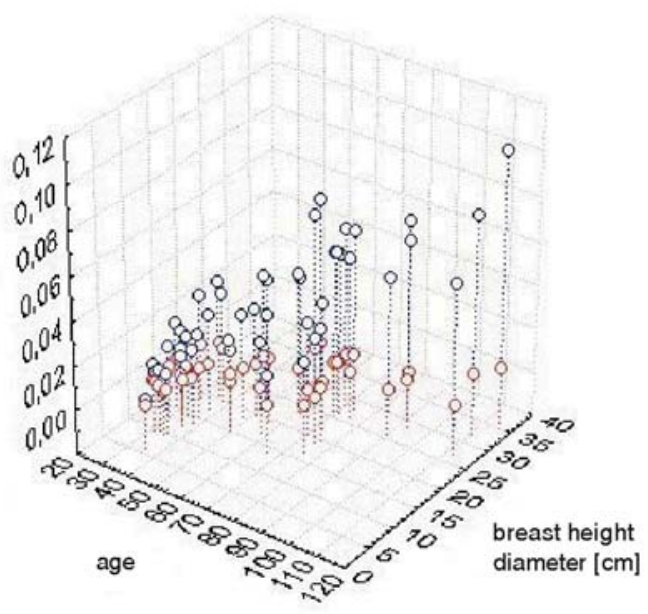

Juvenile wood zone b
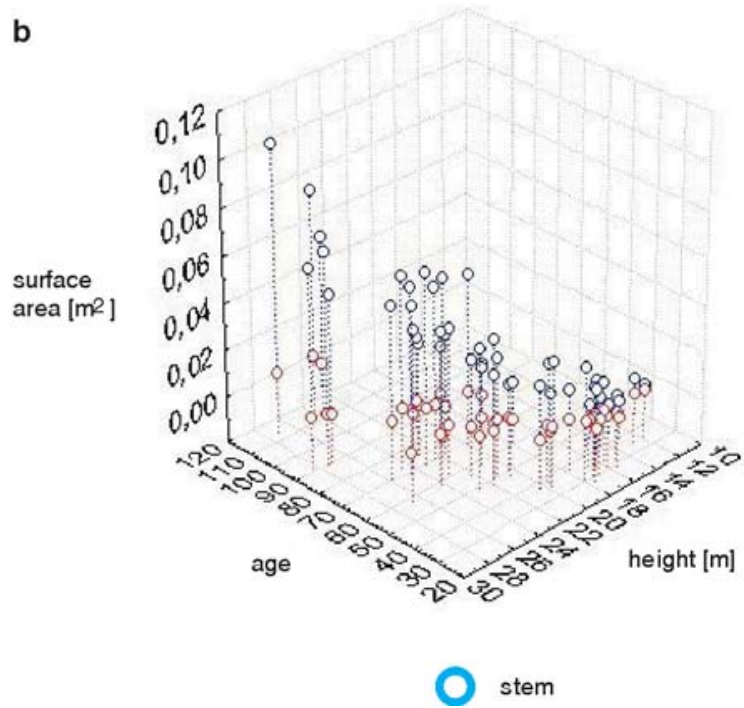

Correlation coefficients: $\quad$ stem cross section area - age, breast height diameter $(\mathbf{r}=\mathbf{0 . 9 8})$

cross section area of juvenile wood zone - age, breast height diameter $(\mathbf{r}=\mathbf{0 . 4 1})$

stem cross section area - age, height $(\mathbf{r}=\mathbf{0 . 8 8})$

cross section area of juvenile wood zone - age, height $(\mathbf{r}=\mathbf{0 . 2 2})$

Fig. 2. Tree mean cross section areas of the stem, including juvenile wood, in relation to age, breast height diameter (a) and height (b).
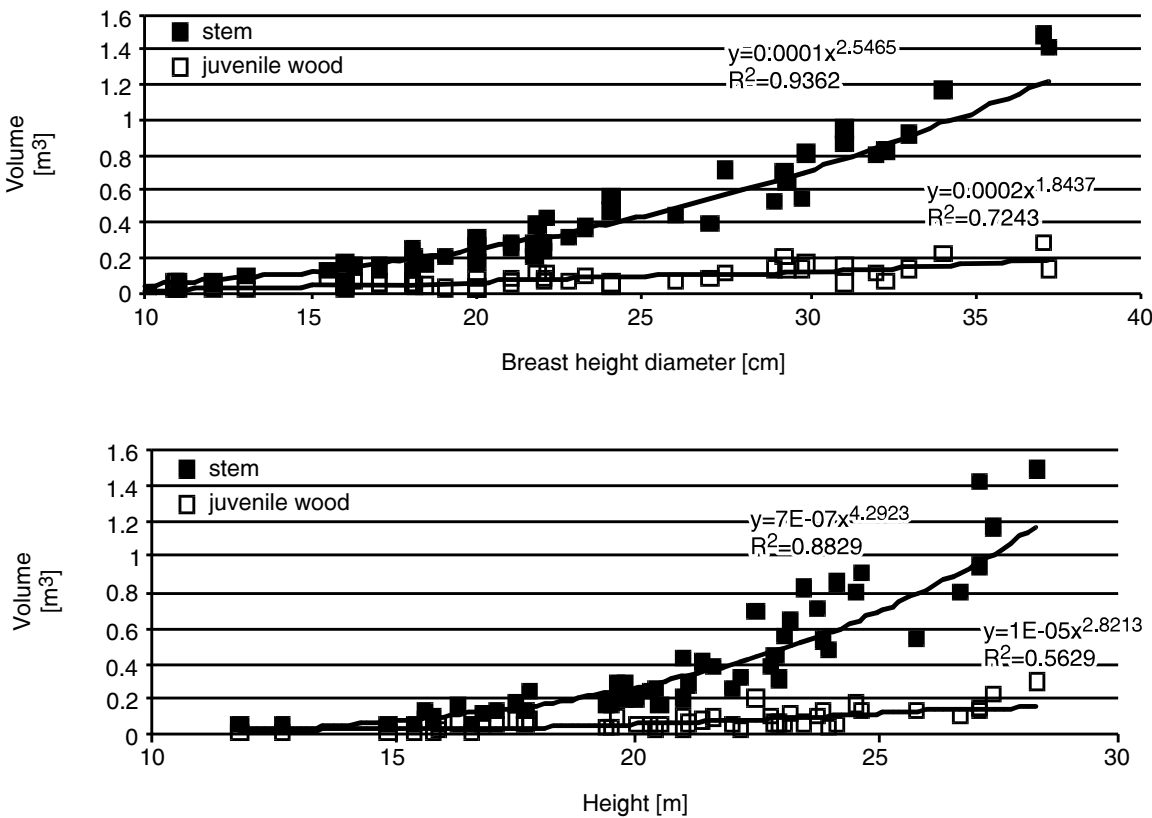

Fig. 3. Interdependence between the volume of the whole stem and juvenile wood and breast height diameter in Scots pine growing in conditions of fresh mixed coniferous forest.

Fig. 4. Interdependence between the volume of the whole stem and juvenile wood and tree height in Scots pine growing in conditions of fresh mixed coniferous forest. 

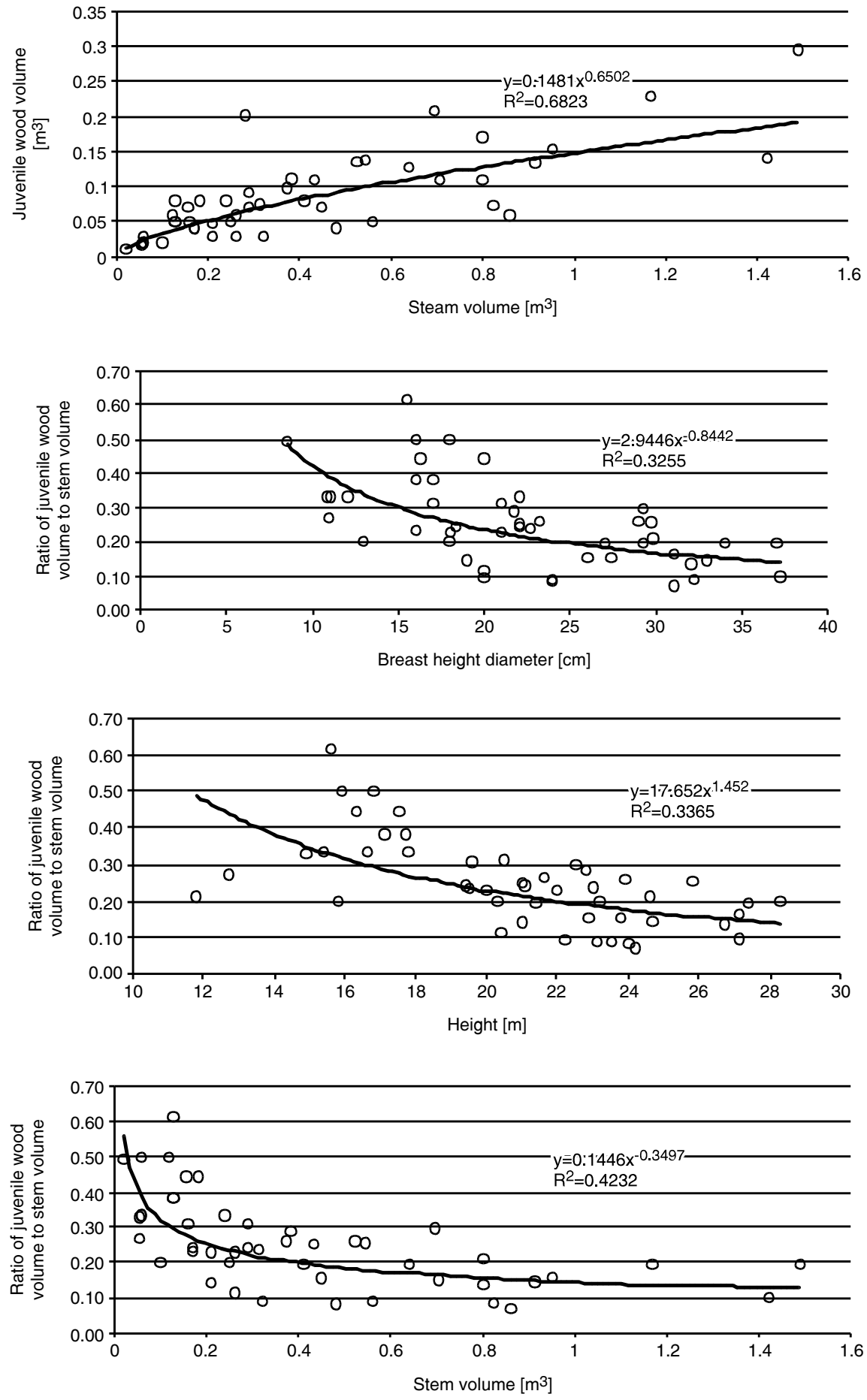

Fig. 5. Interdependence between the juvenile wood volume and the stem total volume in Scots pine trees growing in conditions of fresh mixed coniferous forest.

Fig. 6. Interdependences between the proportion of juvenile wood and breast height diameter in stems of Scots pine growing in conditions of fresh mixed coniferous forest.

Fig. 7. Interdependences between the proportion of juvenile wood and tree height in stems of Scots pine growing in conditions of fresh mixed coniferous forest.

Fig. 8. Interdependences between the proportion of juvenile wood and total volume in stems of Scots pine growing in conditions of fresh mixed coniferous forest. ght - from 11.2 to $26.0 \%$ in the first case and from $6.6 \%$ to $13.8 \%$ in the second (Table 1).

Analysing the mean values and variability coefficients obtained in this study against age classes, it can be said that, generally speaking, the lowest mean values occurred in the earliest stage of pine stand development and they increased with age (moving to later developmental stages), with the exception of the ratio of juvenile wood volume to the stem whole volume, where the ratio is reverse. The maximum variability of the mean cross section areas of the stem, including juvenile wood volume and the proportion of this wood, was found in the IInd age class and decreased significantly with age. Therefore, it can be stated that as the examined pine stands grew older, stem biometric features, juvenile wood volume and proportions became more stable. Figure 2 illustrates the tree trunk mean cross section areas, including juvenile wood, in relation to the age, breast height diameter (a) and height (b).

As the trees grew older and their breast height diameters and heights increased, the mean cross-section areas of stems changed significantly increasing their surfaces considerably. On the other hand, however, the mean cross section area of the stem comprising juvenile wood did not change much (Fig. 2a and b).

Figures 3 and 4 show the interrelationships between the total and juvenile wood volume in pine stems and their breast height diameters (Fig. 3) and heights (Fig. 4).

The stem total volume and the juvenile wood volume depend, respectively, in about $94 \%$ and over $72 \%$ on the breast height diameter and in $88 \%$ and over $56 \%$ - to the 
height as shown by the calculated determination coefficients $\left(\mathrm{R}^{2}\right)$. Once the pine trees exceeded $20 \mathrm{~cm}$ breast height diameter and $20 \mathrm{~m}$ height, a distinct increase in the increment dynamics of stem total volume was noted, whereas the volume of the juvenile wood increased slightly.

The interdependence of juvenile wood volume and stem total volume is characterized in Figure 5.

The results of the volume of juvenile wood are depending in over $68 \%$ on stem total volume. The calculated determination coefficients $\mathrm{R}^{2}$ amounted to 0.6823 .

In this study, the proportion of juvenile wood is expressed by the ratio of this wood volume to the total stem volume. The interdependences between the proportion of juvenile wood and breast height diameter and tree height are characterised by curvilinear correlations (Figs 6 and 7).

The proportion of juvenile wood depended in $33 \%$ on the breast height diameter and in $34 \%$ on the tree height (Figs 6 and 7). The analysis of curve runs characterizing the above-mentioned interrelations reveals that the highest proportions of juvenile wood and a significant dynamics of changes in these proportions occurred in the early stages of tree development, i.e. when the trees were characterized by small breast height diameter and height parameters. During later stages of development, i.e. when the stands were older, the dynamics of changes and the proportion of juvenile wood declines, which should be associated with the increased increment dynamics of stem total volume (Figs 3 and 4), including mature wood.

The proportion of juvenile wood in Scots pine stems depended, in over $42 \%$, on the stem total volume. A high change in dynamics and the highest proportion of juvenile wood occurred in stages of early tree development when the stem total volume did not exceed $0.2 \mathrm{~m}^{3}$ (Fig. 8). Once this volume was exceeded, the proportion of juvenile wood and dynamics of changes were negligible.

\section{DISCUSSION}

The significance of juvenile wood as timber raw material depends, firstly, on the fact that it occurs in each tree and, secondly, that its structure and properties are distinctly different from those of mature wood of the same tree (Hejnowicz 1973, 2002). Both closer to the pith and the tree crown, the fibril helix in the tracheid wall is less steep, the cellulose content is lower, the shrinkage during drying is more severe, the wood is less resistant to the destructive action of fungi and the wood specific density is smaller (Hejnowicz 1973, 2002). In result of the above-mentioned variabilities, we can observe undesirable and exceptionally striking differences in timber functional properties occurring within the stem (Bendsten 1978; Gorman 1985; Senft 1986; Lewark 1986; Zobel and Sprangue 1998).

A thorough knowledge of quantitative relations of juvenile and mature wood in stems of Scots pine trees, of our major forest-forming tree species, is very important for the rationalisation of processing and utilisation of timber raw material harvested from pine stands.

On the basis of the employed equations as well as the knowledge of such parameters as the values of the breast height diameter, tree height and the stem total volume, it is possible to estimate the volume and proportion of juvenile wood in the stem total volume of Scott pine trees growing in conditions of fresh mixed coniferous forest.

\section{CONCLUSIONS}

1. A distinct curvilinear correlation was established in Scots pine trees growing in conditions of fresh mixed coniferous forest type site between the volume and proportion of juvenile wood in tree stems and breast height diameter, tree height and total stem volume.

2 . The values of determination coefficients $\left(\mathrm{R}^{2}\right)$ characterizing the relationship between juvenile wood volume and breast height diameter, tree height and total stem volume amounted to: $0.7243,0.5629$ and 0.6823 , respectively. However, in case when the dependent variable was the share of juvenile wood, and the independent variable included the breast height diameter, tree height and stem total volume, the determination coefficients achieved values of $0.3255,0.3365$ and 0.4232 , respectively.

3 . Bearing in mind the obtained values of determination coefficients $\left(\mathrm{R}^{2}\right)$ characterising the relationship between volume and proportion of juvenile wood, i.e. dependent variables and the breast height diameter, tree height and total stem volume, i.e. independent variables, the regularity should be employed as a method of timber quality evaluation regarding the volume and proportion of juvenile wood in the stems of Scots pine trees growing in conditions of fresh mixed coniferous forest.

\section{LITERATURE CITED}

ASSMANN E. 1961. Waldertragskunde. BLV Bayerischer Landwirtschaftsverlag GmbH, München, Bonn, Wien.

BAO F.C., JIANG Z H, LU X.X., LUO X.Q., HANG S.Y. 2001. Differences in wood properties between juvenile wood and mature wood in 10 species grown in China. Wood Science and Technology, Springer-Verlag, no. 35, pp. 363-375.

BENDTSTEN B.A. 1978. Properties of wood from improved and intensively managed trees. Forest Prod. J. 28: 10-61.

CZURAJ M. 1991. Tablice miąższości kłód odziomkowych i drzew stojących. PWRiL, Warszawa. (in Polish)

GORMAN T.M. 1985. Juvenile wood as a cause of seasonal arching in trusses. Forest Prod. J. 35, 11/25-35.

GROCHOWSKI J. 1973. Dendrometria. PWRiL, Warszawa. (in Polish)

HEJNOWICZ Z. 1973. Anatomia rozwoju drzew. PWN, Warszawa, p. 587. (in Polish)

HEJNOWICZ Z. 2002. Anatomia i histogeneza roślin naczyniowych. PWN, Warszawa. (in Polish)

JAKUBOWSKI M., PAZDROWSKI W. 2003. Percentages of mature wood in trunks of Scots pine (Pinus sylvestris L.) versus selected metric features of tree crowns. Annals of Warsaw Agriculture University - SGGW, Forestry and Wood Technology, no. 53, pp. 138-142.

JAKUBOWSKI M. 2004. Udział bielu, twardzieli, drewna młodocianego i dojrzałego w strzałach sosen zwyczajnych (Pinus sylvestris L.) wyrosłych w różnych warunkach siedliskowych. Sylwan, no. 8, pp. 16-24. (in Polish with English summary)

KRETSCHMANN D.E. 1998. Properties of juvenile wood. Techline - Properties and Use of Wood, Composites, and Fiber Products. 
LARSON R.P. 1969. Wood formation and the concept of wood quality. School of Forestry, Bulletin 74. Yale University, New Haven.

LARSON P.R., KRETSCHMANN D.E., CLARK III A., ISEBRANDS J.G. 2001. Formation and Properties of Juvenile Wood in Southern Pines. A Synopsis. United States Department of Agriculture, Forest Service, Forest Product Laboratory, General Technical Raport, FPL - GTR, 129. p. 42.

LEMKE J. 1966. Korona jako kryterium oceny dynamiki wzrostowej drzew w drzewostanie sosnowym. Folia Forestalia Polonica, Seria A, issue 12, pp. 185-211. (in Polish with English summary)

LEWARK S. 1986. Anatomical and physical differences between juvenile and adult wood. Proc. $18^{\text {th }}$ IVFRO World Congress. Div. 5. Ljubljana 7-21 Sept., p. 272.

PANSHIN A.J., de ZEEUW C. 1980. Textbook of Wood Technology. Nr 1, McGraw - Hill Book Company, New York.

PAZDROWSKI W. 1992. Związek pomiędzy udziałem bielu i twardzieli w miąższości kłód odziomkowych sosen a udziałem obu rodzajów drewna w powierzchni przekroju poprzecznego pnia w miejscu ścięcia i pierśnicy drzew. Sylwan, no. 7, pp. 51-60. (in Polish with English summary)

PAZDROWSKI W., SPŁAWA-NEYMAN S. 2003. Stage growth of trees and its effect on selected properties of Norway spruce wood (Picea abies (L.) Karst). Electronic Journal of Polish Agricultural Universities. volume 6. Series Forestry, pp. 1-7.

PAZDROWSKI W. 2004. The proportion and some selected physical and mechanical properties of juvenile maturing and adult wood of Black pine and Scots pine. Electronic Journal of Polish Agricultural Universities. volume 7. Series Forestry, pp. 1-8.

PAZDROWSKI W., JAKUBOWSKI M. 2000. Objętość korony a udział drewna młodocianego w strzale sosny zwyczajnej $(P i$ - nus sylvestris L.). Materiał III Konferencji Leśnej, IBL. (in Polish)

Praca zbiorowa. 2002. Zasady hodowli lasu. PWRiL, Warszawa. (in Polish)

PUCHALSKI T. 1969. Wybrane zagadnienia z hodowli lasu. Wzrost drzew i drzewostanów. Skrypt Wyższej Szkoły Rolniczej w Poznaniu. (in Polish)

SENFT J.F. 1986. Practical significance of juvenile wood for the user. Proc. $18^{\text {th }}$ IVFRO World Congress. Div. 5. Ljubljana 7 21 Sept., p. 261.

SPŁAWA-NEYMAN S., WOJCIESZYN A. 1995. Zagadnienia wykorzystania na cele konstrukcyjne drewna sosnowego pozyskanego z drzew młodszych klas wieku. Przemysł drzewny, no. 9, pp. 18-20. (in Polish)

WILCHELMSSON L., ARLINGER J., SPĹNGBERG K., LUNQVIST S., GRAHN T. HEDENBERG Ö., OLSSON L. 2002 Models for predicting wood properties in stems of Picea abies and Pinus sylvestris in Sweden. Scandinavian Journal Forest Research, no. 17, pp. 330-350.

WODZICKI T.J. 1964. Różnicowanie rocznego słoja drewna u modrzewia, a zmiany zawartości naturalnych regulatorów wzrostu, w szczególności inhibitorów wzrostu. Dział wydawnictw SGGW, Warszawa. (in Polish)

WODZICKI T.J. 2001. Natural factors affecting wood structure. Wood Science and Technology 35, pp. 5-26.

ZIMMERMANN M.H., BROWN C.L. 1971. Trees Structure and Function. By Springer-Verlag, New York Inc.

ZOBEL B.J., SPRAGUE J.R. 1998. Juvenile wood in forest trees. Springer-Verlag, Berlin-Heidelberg-New York, p. 300. 